\title{
Characteristics of Procurement Methods in Malaysia - Comparing Design-Bid-Build, Design-Build and Construction Management
}

\author{
Azeanita Suratkon $^{1^{*}}$, Riduan Yunus $^{1}$, Rafikullah Deraman $^{1}$ \\ ${ }^{1}$ Jamilus Research Centre, Faculty of Civil Engineering \& Built Environment, \\ Universiti Tun Hussein Onn Malaysia, Batu Pahat, 81300, Johor, MALAYSIA \\ ${ }^{2}$ Faculty of Civil Engineering \& Built Environment, \\ Universiti Tun Hussein Onn Malaysia, Batu Pahat, 81300, Johor, MALAYSIA \\ *Corresponding Author
}

DOI: https://doi.org/10.30880/ijscet.2020.11.03.001

Received 27 January 2020; Accepted 03 May 2020; Available online 30 June 2020

\begin{abstract}
Design-Bid-Build (DBB) or commonly known as Traditional method is the earliest and most prevalent procurement method used in Malaysian construction industry. Design-Build (DB) and Construction Management (CM) procurement methods were later introduced in Malaysia as an endeavour to satisfy and accommodate the increase in project complexity and the need for avoiding drawbacks of the Traditional methods. Each procurement method has different nature and possesses certain characteristics. Therefore, this study was carried out to ascertain and compare the characteristics of these three procurement methods that are implemented in building construction projects in Malaysia. A questionnaire survey was conducted among architects, consultants, contractors and owners or developers to elicit their feedback on the characteristics which were categorised into time, cost, quality, complexity and flexibility, degree of involvement and responsibility allocation and technical expertise. The findings indicated that only DB method almost fulfils all the characteristics under the six categories, whereas, DBB methods garnered agreement only for certain characteristics under time, cost, complexity and flexibility and technical expertise categories. Meanwhile, the only CM method's characteristics that satisfy agreement from the respondents are the often used of fast track approach and lack of certainty in price. This study concludes that when a procurement method is adopted for a construction project, not all the features or characteristics will turn out as expected. There are many factors that contribute and are influential on the success in procurement methods that are worth for further investigation.
\end{abstract}

Keywords: Procurement method, Design-Bid-Build (DBB), Design-Build (DB), Construction Management (CM)

\section{Introduction}

Procurement method or project delivery method is a comprehensive process by which designers, constructors, and various consultants provide services for design and construction to deliver a complete project to the owner (Molenaar, Sobin, Gransberg, McCuen, Korkmaz, \& Horman, 2009). From the perspective of project participants, procurement method is how the various individuals or professionals organise their participation and responsibilities to complete a building project (American Institute of Architects, 1996). The characteristic patterns of participants' involvement, and the disposition of risk among them, constitute the procurement method, or procurement systems for a project (Murdoch 
\& Hughes, 2008). There are three main procurement routes i.e. Design-Bid-Build (DBB) or Traditional method, DesignBuild (DB) and Construction Management (CM).

DBB is a project delivery system in which an owner retains a designer to furnish complete design services and then advertises and awards the separate construction contract based on the designer's completed construction documents (Goldfayl, 1999; Rwelamila \& Meyer, 1999). This system is characterised by a clear division and separation between the design and construction process and responsibilities (Wearne, 1997; Rowlinson, 1999; Martin, 2000). In DBB, apart from a main contract with the owner, the main contractor may enter into several sub-contracts with sub-contractors (for specialised works) and sub-contracts with suppliers (for the supply of construction materials, components or equipment) who are nominated by the owner. The main contractor is responsible for the performance of both nominated subcontractors and nominated suppliers and for the entire construction and completion of the work (Abdul Rashid, 2002).

DB is a method in which the owner retains both design and construction services in the same contract from a single legal entity referred to as the design-builder (Molenaar, et al., 2009). In DB, the central contractual position between owner and contractor is simplified as the design and construction are contractually one package supplied from contractor to owner (Turner, 1995). Based on the owner's need statement, tenderers submit complete proposal for the design, construction and commissioning of the project. The contract between the successful contractor and the owner is normally a lump sum fixed cost and fixed time basis (Abdul Rashid, 2002).

The Construction Management Association of America (CMAA) defines CM as a project delivery system comprising a program of management services applied to a construction project from conception to completion, in order to control time and cost, and to maintain project quality. The service is defined in scope by the specific needs of the project and the owner and performed as a professional service under contract to the owner by a contractor who is function as a construction manager (Levy, 2006). This contractor is employed as a construction consultant to be part of the owner's team and selected on the basis of the experience and qualification of the CM firm or consultant and compensated on the basis of a negotiated fee for the scope of services rendered, i.e. to manage, procure and supervise the construction of a project. The actual construction works are contracted out to a number of package or specialist contractors who are in contract with the owner (Abdul Rashid, Taib, Ahmad, Nasid, Ali, \& Zainordin, 2006).

DBB system, especially the traditional lump sum system is the most frequently used procurement system in Malaysia (Abdul Rashid, et al., 2006; Ng \& Yusof, 2006; Masterman, 2004). According to Rahmat (1997), the majority of projects handled by the architects in this country used the DBB (44.6 percent) followed by DB (36 percent). Both owner (client) sectors public and private in Malaysia used the DBB more compared to other procurement types (Hashim, Li, Yin, Heng, $\&$ Yong, 2006). DBB, as the main procurement routes were found clearly prominent in both public and private sectors, followed by DB and CM (Neighbour, 2006). DBB still dominates Malaysian construction industry with $96.0 \%$ and $96.6 \%$ usages in years 2014 and 2015 respectively based on total number of projects (CIDB, 2016).

Each procurement method has different characteristics to suit with the needs of owner and the project nature. Earlier previous works such as Abdul Rashid, et al. (2006) and Hashim, et al. (2006) discussed the characteristics of these three procurement methods, and $\mathrm{Ng} \&$ Yusof (2006) focused on characteristics of DB procurement solely based on literature review from outside Malaysia. Only Gambo \& Gomez (2015) shared the findings of a survey on project characteristics for DB in Malaysian construction industry. To date, there has been little perception collected from the key parties involved in Malaysian construction projects on comparing the characteristics of the three procurement methods. Therefore, it is worthwhile to study whether the characteristics of each procurement method are really experienced by their community. They may relate their experiences in employing the three procurement methods, to ascertain what characteristics that define and are keys to each procurement method. Therefore, this study was carried out to ascertain and compare the characteristics of these three procurement methods that are implemented in building construction projects in Malaysia.

\section{Procurement Methods and Their Characteristics}

Time is one of the key characteristics that will influence the selection of a procurement method. The DBB system is a sequential process (start from feasibility study, preliminary design, full documentation, tendering to construction and hand over) and subsequently its whole development process is lengthened (Abdul Rashid, et al., 2006; Masterman, 2004; Turner, 1990; Morledge \& Smith, 2013; Neighbour, 2006). Hence, it is often recommended for projects where time is not a critical factor (Masterman, 2004; Taylor, Norval, Hindle, Rwelamila \& McDermott, 1999). In order to speed up the selection of contractor and the commencement of construction, accelerated method, a variant of the DBB system can be adopted in the form of two-stage and negotiated tendering methods (Abdul Rashid, et al., 2006), where the design and construction can run in parallel to a limited extent and allows an early start on site (Davis, Love \& Baccarimi, 2008). In DB, the integration of design and construction into a single entity could save time (Masterman, 2004). The pre-tender process is normally without the design from owner's designer. The process of detail design and construction can be carried out by the contractor almost in parallel and concurrently to each other. Hence, earlier commencement of construction is possible and overall project development period can be substantially reduced (Abdul Rashid, et al., 2006). In CM, early start of construction is practical as only basic tender document need to be prepared and the process of schematic and detail design can be shifted to construction phase. With capability to better manage the design and construction of a project, a contractor can achieve a more efficient and effective coordination of works, materials, 
manpower and plants. As a result, construction time can be shortened. Using CM, a considerable reduction of the overall project time is more promising compared to the other two systems (Abdul Rashid, et al., 2006).

Cost is a very important project objective that may affect the way the project is procured. DBB system provides price certainty to the owner at the very early stage of the project. As the tendering is based on complete working drawings and bill of quantities, ambiguity or uncertainty can be eliminated, thus the owner can get firmer, fairer and more competitive price from the contractors bid, and hence lower project cost can be achieved. As long as variations is minimised, a better cost control to avoid cost increase or inflation is achievable under this system (Masterman, 2004; Morledge \& Smith, 2013). In DB, the cost is fixed at the tender stage or before construction starts, provided that the owner's requirements are adequately specified and changes are not introduced (Abdul Rashid, et al., 2006: Morledge \& Smith, 2013). The cost is often higher than the traditional contracting system because the contractors have to include in the price allocation for many uncertainties due to the lack of design and specification detailing during tender. However, cost saving can be made by the contractor through the reduction of the overall development period, simplification of design and construction work, and some form of incentive offered by owner if he manage to save a significant amount of cost (Abdul Rashid, et al., 2006). Under CM system, the cost of the project is the sum of prices quoted by the package contractors, without extra cost for main contractor's profit. The only additional cost owner has to pay is the fee for construction management consultant. Hence, the overall cost of project procured using this system tends to be lower than those using other methods (Abdul Rashid, et al., 2006). However, using this system, price certainty is not achieved until the last trade packages have been let (Morledge \& Smith, 2013).

Quality is one of the principal feasible objectives of the client in any construction project. As DBB system is designled, A high degree of quality certainty and functional standards under the DBB system could be achieved as the design is completed before the commencement of construction (Hashim, et al., 2006), the owner have direct influence to facilitate a high level of functionality and bespoke quality in the design (Morledge \& Smith, 2013) and the best design, management and construction expertise between consultants and contractor are combined, sufficient time for owner and consultants developing and reviewing the design and specification, as well as preparing better documentation. However, input from the contractor during design stage is missing as he only involves after the completion of the design (Abdul Rashid, et al., 2006). In DB, the contractors could be involved and contribute ideas to improve the design, from the schematic design stage to improve much in the aspect of constructability (Ali, Zakaria \& Che-Ani, 2011). However, despite that the DB contractor, using his knowledge and experience has the opportunity to develop more efficient design and project control programme and to be innovative to further improve the construction process and techniques, the quality of work under this system is often tend to be questionable (Abdul Rashid, et al., 2006; Hashim, et al., 2006). CM system is suitable for projects that require high quality of workmanship (Hashim, et al., 2006). With knowledge and experience as contractor and construction manager, the construction manager is more proficient and more effective in ensuring high quality works, tend to be stricter with the standard and quality of the work done by the package contractors, which will contribute to a better standard and quality of completed project products (Abdul Rashid, et al., 2006).

Complexity of a project can be determined based on the types of physical services involved, the number of sub contractors, resources in terms of labour, plant and materials, the level of technology and the uniqueness of project activities (Songer \& Molenaar, 1997). Since each phase of construction works will be conducted by parties having different expertise, DBB system is suitable for moderately complex projects (Hashim, et al., 2006). Where the design needs vary due to changes in owner need or technology, changes are reasonably easy to arrange and to value (Morledge \& Smith, 2013) and the variations can be kept to the minimum (Hashim, et al., 2006). DB system is suitable for simple and moderately complex projects that rely on the skill and judgment of a contractor (Hashim, et al., 2006), for building that is simple rather than complex, does not highly serviced and does not require high service and technical innovation (Turner, 1990). On the other hand, DB system is mostly adopted for use in projects that are large and complex in nature (Abdul Rashid, 2002; Chan \& Yu, 2005). In conclusion, DB system can be employed for small to large and simple to complex projects. DB system facilitates innovative and flexible approaches such as phased construction, improves the risk management through single point of responsibility, allows utilisation of new materials and technologies, and encourages the development of innovative practices (Rameezdeen \& Ratnasabapathy, 2006). Nevertheless, DB process allows only limited scope for variations and changes, and the right to alter requirements during the fabrication process. The process demands early agreement between employer's requirement and contractor's proposal (Murdoch \& Hughes, 2008). CM system is suitable for large and complex projects, particularly in projects that have overlapping design and construction phase and there is a need for maximum flexibility, for projects with high design innovation where owners want to interfere directly and for more sophisticated projects (Masterman, 2004; Hashim, et al., 2006; Morledge \& Smith, 2013). The project procured using this system can be the one which is simple or technologically complex involving diverse technologies and sub-systems. CM system can accommodate the owner to make minor variations to requirements, as the project proceeds before individual work packages have been let (Murdoch \& Hughes, 2008).

Technical expertise is one of critical aspects that must be possessed by owner, consultant and contractor entities to success any procurement method. In DBB method, typically, design consultant is appointed by owner to prepare complete design and tender documents, before tender invitation to contractors is made. Alternatively, a project management consultant (PMC) can be appointed by the owner to assist the overall management of the works (Abdul Rashid, 2002). In DB, although typically, owner and contractor are the only two parties in the system, consultants may be employed by 
the owner or the contractor. Working under the owner, the consultants or a PMC is to provide assistance in preparing the needs statement and the pre-bid documents (Abdul Rashid, 2002), as well as owner's definitive design criteria for the Design-Builder (DBr) to follow in developing and completing the design (Molenaar, et al., 2009). The degree of design undertaken by the contractor is relative to the extremity of the design and build variant (Knight, 2002). In Malaysia, initially, majority of DB (turnkey) contractors employ design consultants to prepare detailed design and specifications as they do not have their own in-house designers. They also unable to provide full turnkey contracting services due to lack of financial, technical and management capabilities (Abdul Rashid, 2002). It is a typical practice that the DB companies in the Malaysian construction industry outsourcing consultants to execute their projects (Gambo, 2011). A complex project such as hospital where construction and installation of specific rooms and special equipment and coordination with the mechanical and electrical (M\&E) contractor are challenging tasks requires the DB contractor to have sound technical expertise (Jaafar \& Radzi, 2013). Under a CM route, the owner employs the design team and a construction manager is engaged to manage, programme and coordinate the design and construction activities and to facilitate collaboration in order to improve constructability of the design (Morledge \& Smith, 2013; Kwakye, 1997). CM-Advisor offers advice on the use of costs; control of the scope of work, avoiding delays, changes and disputes; improving project design and construction quality and optimal flexibility in contracting and procurement (Olandirin, Olantunji, \& Hamza, 2013). Apart from coordinating and managing the work contractors (package or specialist contractors) during construction stage, the owner also uses construction managers' expertise at pre-contract stage to provide advice on constructability, value engineering, programming, packaging of works, etc. (Singh, 2012).

Depending on the procurement methods, degree of involvement and responsibility allocation among the key project parties vary. In DBB, owner takes the responsibility and risk. He is liable for the design and design team performances (Morledge \& Smith, 2013). Designer or consultants are appointed for design and cost control. Owner delegates most of the management functions to an architect (or civil engineer). The contractor is responsible for carrying out the works. This responsibility extends to all workmanship and materials, and includes all work by subcontractors and suppliers and the coordination among them (Murdoch \& Hughes, 2008; Davis, Love \& Baccarimi, 2008; Singh, 2012). DBB is suitable for owners who want to control the stipulated overall time for the construction projects (Hashim, et al., 2006). In overall, this system provides clear accountability and better design and construction control by the owner (Abdul Rashid, et al., 2006). In DB, higher level of owner's involvement is required as the owner will directly deals with the contractor on any matters and issues related to the project, especially design without mediating consultants (Turner, 1995; Murdoch \& Hughes, 2008). Risks that are associated to the project which are transferred by the owner to the contractor in this system are more than any other procurement approach (Muhammed, 2005). This could largely be attributed to the DB contractor's single point responsibility nature i.e. to be in total responsibility for the design and the construction phases of the contract (Beard, Loulakis \& Wundram, 2001). DB allows the owner to transfer risk to the contractor. Therefore, some owners are choosing DB to avoid liability and not so much about its integration benefits (Griffith, Knight, \& King, 2003). In CM, owner takes on the most active involvement as the role of a main contractor is completely removed from the contractor who performs as a construction manager (Murdoch \& Hughes, 2008). The construction manager is only in a consulting role; i.e. giving advice, coordinate contracts of trade contractors, perform some supervisory and management responsibility, and is not at risk for the amount of the construction contract (Murdoch \& Hughes, 2008; Beard, Loulakis \& Wundram, 2001). In adopting CM system, the owner will be closely involved in each stage of design and construction through its project management team that is technically and commercially resourceful in assessing the recommendations of the construction manager and taking the necessary actions. Therefore, this approach is suitable only for expert and experienced owner (Morledge \& Smith, 2013).

\section{Methodology}

\subsection{Questionnaire Development}

The purpose of the questionnaire survey was intended for feedback on the characteristics of the three procurement methods which are categorised under six groups of items i.e. time, cost, quality, complexity and flexibility, degree of involvement and responsibility allocation, and technical expertise. A five-point Likert-scale with options ranging from "strongly agree" to "strongly disagree" has been adopted to elicit feedback on the characteristics.

\subsection{Data Collection and Analysis}

Key parties involved in construction projects were targeted as respondents for a questionnaire survey to achieve the objective of the research. Questionnaire forms were distributed to 300 respondents (i.e., 100 owners (and developers) from public and private sectors, 100 Grade 7 contractors registered with Construction Industry Development Board (CIDB), 50 architects, and 50 consultants) where their companies are located or based in Johor, Melaka and Kuala Lumpur with their construction projects are all over Malaysia. After screening 105 returned questionnaires, only 72 are complete for analysis which accounted for $24 \%$ valid response rate (Table 1). This is close to the 25-30\% normal response rate for construction research as highlighted by Fellows \& Liu (2008). 
Table 1- Questionnaire Sent and Received, and Valid Responses

\begin{tabular}{cccc}
\hline \multirow{2}{*}{ Respondents } & \multicolumn{3}{c}{ Questionnaires } \\
\cline { 2 - 4 } & Sent (No.) & Returned (No., \%) & Valid (No., \%) \\
\hline Architect & 50 & $13,4.3 \%$ & $9,3.0 \%$ \\
Consultant & 50 & $19,6.3 \%$ & $9,3.0 \%$ \\
Contractor & 100 & $67,22.3 \%$ & $50,16.7 \%$ \\
Client/ & 100 & $6,2.0 \%$ & $4,1.3 \%$ \\
Developer & $\mathbf{3 0 0}$ & $\mathbf{1 0 5}, 35.0 \%$ & $\mathbf{7 2 , 2 4 . 0 \%}$ \\
Total & &
\end{tabular}

In order to gather the level of agreement on the importance of the three procurement methods' characteristics, average index (AI) analysis based on (Abdul Majid \& McCaffer, 1997; Suratkon, Chan, \& Jusoh, 2016; Abdul Rahman \& AlEmad, 2018) was adopted. The AI analysis is used as it pools all respondents' responses together and provides a single conclusive level of agreement. The interpretation for AI values is shown in Table 2.

Table 2 - Average Index Values and Interpretations

\begin{tabular}{|c|c|}
\hline Average Index (AI) & Level of Agreement \\
\hline $0.00 \leq \mathrm{AI} \leq 1.49$ & Strongly Disagree \\
\hline $1.50 \leq \mathrm{AI} \leq 2.49$ & Disagree \\
\hline $2.50 \leq \mathrm{AI} \leq 3.49$ & Neutral or Undecided \\
\hline $3.50 \leq \mathrm{AI} \leq 4.49$ & Agree \\
\hline $4.50 \leq \mathrm{AI} \leq 5.00$ & Strongly Agree \\
\hline
\end{tabular}

\section{Results and Discussion}

\subsection{Background of the Respondents}

Based on the valid response, the profile of respondents comprises the following: contractor (69.4\%), consultant $(12.5 \%)$, architect $(12.5 \%)$, and owner or developer $(5.6 \%)$. The majority $(61.1 \%)$ of the respondents have bachelor degree. Respondents with higher degree level (master and $\mathrm{PhD}$ ) accounted for $20.8 \%$, and the remaining $18.1 \%$ have diploma degree. In terms of experience, $89 \%$ of the respondents have worked in the construction industry for more than 10 years (Table 3 ). This should provide a substantially reliable data for this study and the analysis and results thereof are likely to be reflective of the key construction players' opinion on real practice of procurement methods in Malaysian construction industry.

Table 3 - Respondents' Working Experience in Construction Industry

\begin{tabular}{lc}
\hline \multicolumn{1}{c}{ Years of working experience } & (No. of respondents, \%) \\
\hline Less than or 5 years & $5,7 \%$ \\
6 to 10 years & $3,4 \%$ \\
11 to 15 years & $10,14 \%$ \\
More than or 16 years & $54,75 \%$ \\
\hline
\end{tabular}

\subsection{Analysis of the Characteristics of Procurement Methods}

The six groups of characteristics of procurement methods have been identified based on the literature review conducted at the beginning of this study. A reliability test was conducted using Cronbach Alpha on the items of each group characteristics. The obtained total Cronbach Alpha value is 0.79982 which indicates consistency of data is high and acceptable, as the value is more than 0.7 (Pallant, 2011). The characteristics under each group and their AI values according to the procurement methods based on the respondents' feedback are discussed in the following subsequent sections.

\subsubsection{Time-related characteristics}


As shown in Table 4, DB with AI value of 3.61 is the only procurement method perceived as suitable to be adopted for project that requires urgent completion. This is in agreement with (Singh, 2012) that point out that DB would generally be suitable in cases where the speed from inception to final completion needs to be maximised as much as practicable. DBB and DB were perceived as have high probability to be completed early. This is an agreement with (Gransberg, Koch, \& Molenaar, 2006) who found that $54 \%$ of the owners in Malaysia are satisfied with the completion rate of projects that employ traditional procurement methods. However, the CM garnered the lowest level of agreement in this matter. This is a clear contradiction to the fact identified by (Abdul Rashid, et al., 2006) that using CM, the overall project time can be reduced significantly in comparison to the other two procurement systems.

Table 4 - Time-related Characteristics

\begin{tabular}{lccc}
\hline \multicolumn{1}{c}{ Characteristics } & DBB & DB & CM \\
\hline Suitable for project requires urgent completion & 3.25 & 3.61 & 2.74 \\
High probability of project to be completed early & 3.64 & 3.56 & 2.06 \\
Earlier start of construction than under traditional methods & - & 3.94 & 2.71 \\
Fast track is often used & 4.12 & 4.27 & 4.11 \\
Concurrent design and construction work is possible & - & 3.99 & 2.28 \\
\hline
\end{tabular}

Under DB, the respondents agreed that earlier start of construction under DBB is likely as the pre-tender process is simplified without design from owner's designer and detail design and construction work can be done more or less simultaneously to each other (Abdul Rashid, et al., 2006). This is consistent with the respondents' feedback that fast track is often used and concurrent design and construction is possible under DB route. Under CM system, the respondents' feedback is against the highlight by Morledge \& Smith (2013) that earlier start of construction is possible as the trade contractors are appointed as soon as the design for that element of work is completed. The survey also revealed that fast track is often used by the respondents under DBB and DB systems.

\subsubsection{Cost-related characteristics}

Cost-related characteristics and the level of respondents' agreement are summarised in Table 5. With AI value of 3.82, the respondents gave their attestation that under DB system, project cost is agreed before design phase start is something that they successfully experienced in their DB projects. The survey revealed it is uncommon that under DB cost is lower than under DBB method. This is due to the price offered by the DB contractor includes allocation for uncertainties that may arise from lack of design and specification detailing (Abdul Rashid, et al., 2006). The findings did not support that using CM system the overall project cost can be lower than those using other procurement system.

Table 5 - Cost-related Characteristics

\begin{tabular}{lccc}
\hline \multicolumn{1}{c}{ Characteristics } & DBB & DB & CM \\
\hline Project cost is agreed before design phase start & - & 3.82 & - \\
Lower total project cost than under traditional method & - & 2.82 & 3.14 \\
High probability of project is completed with a predetermined cost & 2.86 & 3.54 & 2.65 \\
\hline
\end{tabular}

Only DB is attested by the respondents (with AI value of 3.54) to have high probability of projects that can be completed with a predetermined cost. This is possible as the DB contractor shoulders the risk of his estimate of the actual scope of work and the consequent price quoted being incorrect under fixed price contract or lump sum contract (Singh, 2012). The respondents disagreed that the DBB and CM systems have high probability of project to be completed with a predetermined cost. DBB system permits price certainty but it is subject to formal variations ordered by the owner and meanwhile, lack of certainty in price is one the limitations of the CM system (Singh, 2012).

\subsubsection{Quality-related characteristics}

Table 6 shows the agreement levels of respondents towards quality-related characteristics for each procurement methods. DB procurement was agreed by the respondents to satisfy all the quality-related characteristics. This is in contrast with Abdul Rashid, et al. (2006) that commented that the quality of the work under DB system is often questionable. As for DBB system, with AI values (3.35, 3.28 and 3.18) suggesting indecisive agreement; the respondent did not acknowledge that this system in reality offers all the quality-related characteristics. With the lowest AI values, similarly the CM system garnered disagreement for all the quality-related characteristics from the respondents. This is a 
complete contradiction with what have been discussed in literatures that using CM system, a better standard and quality of products can be materialised mainly through the capability of the professional construction manager in ensuring high quality works by the package contractors.

Table 6 - Quality-related Characteristics

\begin{tabular}{lccc}
\hline \multicolumn{1}{c}{ Characteristics } & DBB & DB & CM \\
\hline High quality of construction work completed & 3.35 & 3.57 & 2.35 \\
High satisfaction in terms of function and aesthetic & 3.28 & 3.81 & 2.35 \\
Specifications used is highly satisfy the contract conditions & 3.18 & 3.83 & 2.10 \\
\hline
\end{tabular}

\subsubsection{Complexity and flexibility}

As depicted in Table 7, the survey reveals that only DB procurements was rated to be suitable to be used for large, complex and high-tech project (AI value of 3.94), and are used when owner does not have technical expertise (AI value of 3.71). This is a clear attestation to the findings by Gambo \& Gomez (2015) where 'suitable for complex projects' is the first-ranked characteristic of the DB procurement. The premise that DBB system is suitable for moderately complex project as highlighted in literatures is attested by the findings of this study. In contrast, from the findings, CM approach was perceived as not be able to suit the needs for large, complex, high-tech projects where the owner is in dire need for technical expertise. This is totally disagreement with the facts pointed out in the literatures.

Table 7 - Complexity and Flexibility

\begin{tabular}{lccc}
\hline \multicolumn{1}{c}{ Characteristics } & DBB & DB & CM \\
\hline Suitable for large and complex project & 3.06 & 3.94 & 2.13 \\
Ideal for high-tech project & 3.36 & 3.93 & 2.22 \\
Used when client does not have technical expertise & 3.26 & 3.71 & 2.42 \\
High flexibility of design for changes during construction & 3.56 & 3.64 & 2.75 \\
\hline
\end{tabular}

In terms of high flexibility of design for changes during construction, DBB and DB are confirmed by the respondents to possess this characteristic. DBB system affords the owner a relatively high degree of flexibility to carry out changes through inclusion of two mechanisms in the contract: clear express provisions permitting variations and items of Prime Cost (PC) Sum and Provisional Sum (Singh, 2012). Despite the fact that DB process allows only limited scope for variations and changes pointed in literatures, the survey reveals that DB has high flexibility in this matter. The price and time adjustment and knock-on impact on the contractor's design and production activities due to the any changes or alterations should be carefully considered (Singh, 2012). Meanwhile, indicated by AI value (2.75) that shows indecisive agreement, the respondents suggested that the advantage of greater flexibility for changes that CM system can offer is questionable.

\subsubsection{Technical Expertise}

Table 8 reports the agreement level of the respondents on the technical expertise necessary for execution of the procurement routes. Under DB system, with 4.35 AI value, the respondents agreed that it is very important for contractor to have a clear understanding of design work and expertise to perform design as design capability is a must for a DB contractor. In contrast, as reflected in low AI value, having good understanding of design work is relatively less important under DBB and CM approaches as the design work is normally performed by owner's design team. The survey reveals that it is still important for owner to have in-house design team in employing DB approach where the complete design is to be furnished by the contractor. However, the finding suggests that this is not a necessity under CM approach as the design can be fully out-sourced to a design team. With considerably high agreement level of AI value (4.38), the respondents perceived that under DB method, it is a necessity for the DB contractor is a specialist contractor with certain technical expertise. However as indicated by low AI value (2.44), this is not the case in CM approach.

Table 8 - Technical Expertise

$\begin{array}{llll}\text { Characteristics } & \text { DBB } & \text { DB } & \text { CM }\end{array}$


Contractor has a clear understanding of design work

Contractor has expertise to perform design work

Client has in-house design team

Specialist contractor who has technical expertise is a necessity

Client appoint PMC/ construction manager to assist in pre-design and design phases

Client appoint PMC/ construction manager to advise on project scope, constructability, costing, scheduling and technical

$\begin{array}{ccc}3.07 & 4.35 & 1.96 \\ - & 3.51 & - \\ - & 3.64 & 2.61 \\ - & 4.38 & 2.44 \\ 3.47 & 3.90 & 2.35 \\ - & & 1.57\end{array}$

Literature highlights that the appointment of PMC/construction manager is an essential feature especially for CM approach. From the survey however, it indicates that appointment of PMC/Construction Manager by owner to assist in pre-design and design phases as well as to advice on project scope, constructability, costing, scheduling and technical are not a normal practice under CM. It is interesting to note that the respondents perceived that in DB method, owner still need to appoint construction manager to assist in pre-design and design phases. This construction manager as a consultant may assist the owner developing the request for qualification (RFP) and the design content of the RFP and performing design review (Gransberg, Koch, \& Molenaar, 2006).

\subsubsection{Degree of involvement and responsibility allocation}

As shown in Table 9, the findings confirmed that in DB, owner has to highly involve in design and construction process and he directly seeks contractor consultation without consultant intervention during project execution. This is in agreement with Turner (1995) and Murdoch \& Hughes (2008) that highlighted such level of owner's involvement and direct dealing with DB contractor on any project's matters and issues are necessary. The survey revealed that owner still appoints designer team to prepare preliminary design, before the DB contractor completing the design. This requires high degree of consultants monitoring towards DB contractor.

Table 9 - Responsibility Allocation

\begin{tabular}{lccc}
\hline \multicolumn{1}{c}{ Characteristics } & DBB & DB & CM \\
\hline High degree of client involvement in design and construction phases & 2.39 & 3.85 & 2.71 \\
High transfer of risk from client to contractor & 3.21 & 3.74 & 2.33 \\
High degree of consultants monitoring towards contractors & 3.00 & 3.90 & 2.35 \\
Client appoint designer team to prepare preliminary design & - & 3.76 & - \\
Client directly seeks contractor consultation without consultant & - & 3.81 & - \\
intervention during project execution & - & 3.88 & - \\
Contractor is fully responsible for design work & - & & - \\
\hline
\end{tabular}

In terms of risk allocation, it is attested that in $\mathrm{DB}$, owner transfer most of the risk to the contractor and contractor is fully responsible for design and construction works. From the survey, it is not conclusive that both DBB and CM procurement methods require high degree of owner involvement in design and construction phases and consultants monitoring towards contractors. Those characteristics were pointed out in many literatures and research works, but were not supported by the response as the AI values are fall under disagreement to indecisive agreement. Under DBB approach owner retains the liability for design and design team performances. While under CM approach, apart from design and design team performances, owner is also responsible for the work/trades contractor performances. These mean only low transfer of risk from owner to contractor. With low AI values rated by the respondents for both DBB and CM, the premises are supported by this finding.

\section{Conclusion}

The characteristics of the three procurement methods in construction projects were ascertained through the feedback given by the respondents. This study found that DB method has the most characteristics categorised under time, cost, quality, complexity and flexibility, degree of involvement and technical expertise being rated agreed by the respondents. Being the dominant procurement method in Malaysian construction industry, projects procured using DBB method is agreed to have high probability to be completed early, utilise fast track approach when necessary, have high flexibility to allow changes of design during construction, and utilise PMC when needed by the owner to assist in pre-design and design phases. As for CM method, the characteristics that were considered as important are only the often used of fast track approach and lack of certainty in price. Utilising a procurement method with its characteristics to satisfy the needs of owner and be compatible with nature of project requires many efforts and supporting factors to make the project a 
successful one. Regardless of the procurement system adopted, the factors that contribute and are influential on the success of the procurement methods and the project as a whole are worth for further investigation.

\section{Acknowledgement}

Special thanks for Nurul Atikah Mohamad Ghazi, Nursyahirah Azmadi, and Muhammad Shahrul Nazeri Nahlius for conducting the survey during their Final Year Project 2.

\section{References}

Abdul Majid, M.Z. and McCaffer, R. (1997). Assessment of Work Performance of Maintenance Contractors in Saudi Arabia. Journal of Management in Engineering, ASCE, September/October, 1997

Abdul Rahman, I. and Al-Emad, N. (2018). Significant Leadership Qualities for Saudi Arabia Construction Leaders. MATEC Web of Conferences 203, 02003 (2018), 4th International Conference on Civil, Offshore \& Environmental Engineering (ICCOEE 2018), EDP Sciences, 1-8

Abdul Rashid, K. (2002). Construction Procurement in Malaysia. Kuala Lumpur: IIUM Press

Abdul Rashid, R., Taib, I.M., Ahmad, W.N.W, Nasid, M.A., Ali, W.N.W., and Zainordin, Z.A. (2006). Effect of Procurement Systems on the Performance of Construction Projects. Conference on Construction Industry, Padang, Indonesia

Ali, A.S., Zakaria, N. and Che-Ani, A-I. (2011). The Effect of Procurement System towards the Performance of Refurbishment Works. Recent Researches in Energy, Environment, Devices, Systems, Communications and Computers, $70-75$

American Institute of Architects, California Council (AIACC) (1996). Handbook on Project Delivery. California: AIACC

Beard, J., Loulakis, M. and Wundram, E. (2001). Design-build: Planning Through Development. 1st ed. New York: Mc Graw Hill

Chan, E. and Yu, A. (2005). Contract Strategy for Design Management in the Design and Build System. International Journal of Project Mangement , 23(3), 630-39

CIDB, "Construction Quarterly Statistical Bulletin”, 2016, http://www.cidb.gov.my/cidbv5/images/content/bisnes/ buletin/2016/bahg.-2-q1.pdf, accessed in Jan 2017

Davis, P., Love, P., Baccarimi, D. (2008). Building Procurement Methods. Report, Project Affiliates Curtin, University of Technology, Western Australia Department of Housing \& Work, Royal Melbourne Institute of Technology

Fellows, R. and Liu, A. (2008). Research Methods for Construction. West Sussex: Wiley-Blackwell

Gambo, M.M. (2011). A Study of Current Design \& Build Procurement Approach Practice based on the Client's Specific Expectations in the Malaysian Construction Industry. Master Thesis, Johor: Universiti Tun Hussein Onn Malaysia

Gambo, M.M. and Gomez, C.P. (2015). Project Characteristics for Design and Build Procurement in Malaysian Construction Industry. Journal of Engineering and Technology, Vol 6. No. 1 January-June 2015

Goldfayl, G. (1999). Construction Contract Administration. Victoria: Deakin University Press

Gransberg, D.D., Koch, J.A., Molenaar, K.R. (2006). Preparing for Design-Build Projects: A Primer for Owners, Engineers, and Contractors. Virginia: ASCE

Griffith, A., Knight, A., and King, A. (2003). Best Practice Tendering for Design and Build Projects. London: Thomas Telford

Hashim, M., Li, M.C.Y., Yin, N.S, Heng, S.M, and Yong, T.L. (2006). Factors Influencing the Selection of Procurement Systems by Clients", Conference on Construction Industry, Padang, Indonesia

Jaafar, M. and Radzi, N.M. (2013). Level of Satisfaction and Issues with Procurement Systems Used in the Malaysian Public Sector. Australasian Journal of Construction Economics and Building, 13(1), 50-65 
Knight, A.D., Griffith, A. P. King (2002). Supply Side Short-circuiting in Design and Build Projects, Management Decisions, Vol. 40 No. 7, 655 -659. MCB UP Ltd

Kwakye, A.A. (1997). Construction Project Administration in Practice. Longman

Levy, S.M. (2006). Design-Build Project Delivery. New York: McGraw-Hill

Martin, R. (2000). Pitfalls to be Avoided by Design and Build Contractors, www.jrk.com.my/articles/pitfalls.htm, accessed in March 2014

Masterman, J.W.E. (2004). An Introduction to Building Procurement Systems”, $2^{\text {nd }}$ ed., London: E \& F.N Spon

Molenaar, K.R., Sobin, N., Gransberg, D., McCuen, T., Korkmaz, S. and Horman, M. (2009). Sustainable, High Performance Projects and Project Delivery Methods: A State-of-Practice Report

Morledge, R. and Smith, A. (2013). Building Procurement. West Sussex: Wiley-Blackwell

Muhammed, N.H. (2005). A Case Study on the Management of UTM New Hostel Based on Design and Build Arrangement. Msc Thesis. Johor: Universiti Teknologi Malaysia

Murdoch, J. and Hughes, W. (2008). Construction Contracts: Law and Management. London: Spon Press

Neighbour, K. (2006). A Guide to Construction Projects Best - Practices for the Procurement and Delivery of A Project

Ng., W.S. and Yusof, A.M. (2006). The Success Factors of Design and Build Procurement Method. Proceedings of the 6th Asia-Pacific Structural Engineering and Construction Conference (ASPEC), September 5, 2006, pg C1-C11

Olandirin, O.T., Olantunji, S.O. and Hamza, B.T. (2013). Effect of Selected Procurement Systems on Building Project Performance in Nigeria. International Journal of Sustainable Construction Engineering \& Technology, 4(1), 48-62

Pallant, J. (2011). SPSS Survival Manual: A Step by Step Guide to Data Analysis Using SPSS for Program. 4th ed. Australia: Allen \& Unwin

Rahmat, I. (1997). The Planning and Control Process of Refurbishment Projects”, PhD Thesis, UK: University College London

Rameezdeen, R. and Ratnasabapathy, S. (2006). A Multiple Decisive Factor Model for Construction Procurement System Selection. Proceedings of the 6th Annual Research Conference of the Royal Institution of Chartered Surveyors, UK: University College London

Rowlinson, S., "A Definition of Procurement Systems". In Procurement Systems: A Guide to Best Practice in Construction, ed. S. Rowlinson and P. McDermott., London: E \& FN Spon, 1999, 27-51

Rwelamila, P.D. and Meyer, C. (1999). Appropriate or Default Project Procurement Systems. Cost Engineering, 41 (9): 40-44

Singh, H.K.S. (2012). Pre-Contract Award Practice. $2^{\text {nd }}$ ed. Selangor: LexisNexis

Songer, A.D., Molenaar, K.R. (1997). Project Characteristics for Successful Public-Sector Design-Build, Journal of Construction Engineering and Management, March 1997, pp. 34-40

Suratkon, A., Chan, C-M. and Jusoh, S. (2016). Indicators for Measuring Satisfaction Towards Design Quality of Buildings. International Journal of GEOMATE, Aug., 2016, Vol. 11, Issue 24, 2348-2355

Taylor, R.G., Norval, G.H. Hindle, M.B. Rwelamila, P.D. and McDermott, P. (1999). From Conventionally Orientated to Developmentally Orientated Procurement Systems: Experiences from South Africa. In Procurement Systems: A Guide to Best Practice in Construction, ed. Rowlinson, S. and McDermott, P., London: E \& FN Spon, 163-183

Turner, A. (1990). Building Procurement. London: Macmillan Education Ltd 
Turner, D.F. (1995). Design and Build Contract Practice. Essex: Longman Scientific \& Technical

Wearne, S. (1997). Innovations in Procurement - Why, and to Where? Questions for Research. In Procurement - A Key to Innovation. Canada: CIB Proceeding, 781-790 